\title{
KAROLINUM OČIMA KRAKOVSKÉHO PROFESORA: NÁVŠTĚVY LÉKAŘE FRYDERYKA HECHELA V PRAZE V ŘÍJNU 1843 A V ČERVENCI 1846
}

\author{
MAREK ĎURČANSKÝ
}

\section{CAROLINUM THROUGH THE EYES OF A CRACOW PROFESSOR: PHYSICIAN FRYDERYK HECHEL AND HIS VISITS TO PRAGUE IN OCTOBER 1843 AND JULY 1846}

This contribution consists of the biographical introduction and translation of source material pertaining to the history of Charles-Ferdinand University in the nineteenth century, in particular two fragments from the memoirs of the Polish physician Fryderyk Hechel (1795-1851). Hechel, a professor at the Jagiellonian University in Cracow, visited Prague twice (in 1843 and in 1846) and described both of these visits in his memoirs. The second fragment contains a unique, detailed description of a graduation ceremony in the great hall of the Carolinum.

Keywords: Charles-Ferdinand University - promotions - memoirs - Czech-Polish contacts

DOI: $10.14712 / 23365730.2018 .35$

Profesor lékařské fakulty Jagellonské univerzity Fryderyk Hechel nepatří mezi nejvýznamnější osobnosti tohoto staroslavného učení. Jeho pedagogické působení nebylo př́liš dlouhé (zemřel relativně mlád) a ani jeho odborné dílo není právě rozsáhlé. Do širšího povědomí se dostal až bezmála sto let po své smrti, kdy byly vydány jeho rozsáhlé paměti, do té doby zcela neznámé. Ani všeobecnější recepci jeho posmrtně vydaných textů doba príliš nepřála - první část pamětí byla vydána $\mathrm{v}$ předvečer druhé světové války, druhá část v chmurném ovzduší počátku padesátých let. ${ }^{1}$ Snad i z tohoto důvodu nebyly dosud využity pasáže, v nichž Hechelovy paměti představují významný pramen také $\mathrm{k}$ dějinám českých zemí. Tento nadšený cestovatel totiž několikrát navštívil Prahu a některá lázeňská centra, na sklonku života již čistě ze zdravotních důvodů. Cílem autora těchto řádků je upozornit na toto zajímavé svědectví a umožnit snadnější využití pasáží týkajících se Prahy a zejména Karlo-Ferdinandovy univerzity prostřednictvím českého překladu.

Nejprve je nutné krátce představit samotného Fryderyka Hechela. ${ }^{2}$ Narodil se ve Vilně 30. bř̌ezna 1795 do národnostně smíšené rodiny - otec byl Němec protestantské víry, kterou

1 Władysław Szumowski (ed.), Człowiek nauki taki jakim byt. Pamiętniki profesora Uniwersytetu Jagiellońskiego Fryderyka Hechla, I-II, Kraków 1939; Fryderyk Hechel, Kraków i ziemia krakowska w okresie Wiosny Ludów, wyd. Henryk BARYCZ, Wrocław 1950.

2 O něm přehledně Ludmila Krakowiecka, Fryderyk Hechel, in: Polski słownik biograficzny, XI, Wrocław Warszawa - Kraków 1960-1961, s. 327-328; podrobněji pak Henryk BARYCZ, Wśród gawędziarzy, pamiętnikarzy i uczonych galicyjskich, I, Kraków 1963, s. 157-172; Zdzisław MAREK, Fryderyk Hechel (1794-1851). 
po něm přejal i syn, matka Polka a katolička. Fryderyk se měl původně vyučit $\mathrm{v}$ otcově sedlářské dílně, ale kombinace ambic, nadání a píle mu umožnila vystudovat gymnázium. Poté se zapsal na vilenskou univerzitu, zažívající tehdy jedny z nejlepších roků ve svých dějinách. Zde se mj. seznámil s Adamem Mickiewiczem. Studia ukončil doktorátem z medicíny v roce 1818. Po nedlouhé praxi, během níž publikoval první odborné studie, odjel na sklonku roku 1820 jako vychovatel mladého šlechtice Józefa Straszewicze na cestu po západoevropských univerzitách. Navštívil Itálii, Francii, Anglii, Skandinávii (jeho cesta do Laponska je první doloženou cestou Poláka do těchto končin), až se nakonec usadil v Německu. Odsud se v roce 1834 přihlásil do konkurzu na profesora dějin medicíny, soudní medicíny a policejního lékařství na Jagellonské univerzitě v Krakově. Zbytek svého života a odborné kariéry pak spojil právě s lékařskou fakultou krakovské univerzity, přičemž v oblasti dějin medicíny je považován za jednu ze zakladatelských osobností oboru. V národnostně vyhraněném prostředí se tento liberální světoobčan a polyglot rychle polonizoval, účastnil se společenského života a zastával řadu veřejných funkcí, mimo jiné ve vedení krakovského divadla. Publikoval několik prací z oborů, které vyučoval na univerzitě, ale také brožuru o nebezpečí alkoholismu. Řadu let trpěl žlučovými kameny; tato choroba jej také přivedla do českých a moravských lázní, prričemž během pobytu v Jeseníku (Gräfenbergu) 7. května 1851 zemřel a byl tam pochován.

Paměti Fryderyka Hechela byly psány na přelomu třicátých a čtyřicátých let 19. století, záznamy z dalších let jeho života pak mají podobu pravidelně vedeného deníku. Rukopis se dostal do sbírek Polské akademie umiejętności, jejíž členové - historik medicíny Władysław Szumowski a historik Henryk Barycz, zaměřený především na dějiny školství - text připravili k vydání. $Z$ této edice pocházejí také pasáže o pobytu v Praze, jež v překladu do češtiny níže předkládáme. Přejímáme i grafickou podobu textu, včetně použití kurzívy. Komentáře v poznámkách byly doplněny nově (původní edice neobsahuje věcné vysvětlivky).

Ke kontextu je třeba dodat, že Hechelův první pražský pobyt souvisel s jeho větší cestou v létě a na podzim roku 1843, kterou podnikl jako doprovod svého žáka Stanisława Nowowiejského (jeho bohatý otec cestu platil). Během několika měsíců navštívil Slezsko, kde se ve Vratislavi setkal s Janem Evangelistou Purkyněm, severní Německo, Anglii, Holandsko, Švýcarsko a cestou přes Mnichov, Prahu, Jeseník a Opavu se vracel do Krakova. Během krátkého pražského pobytu počátkem ř́ijna 1843 stihl Hechel navštívit Karolinum i Všeobecnou nemocnici. V Jeseníku se pak poprvé setkal s Priessnitzem, který se ale k představiteli oficiální lékařské vědy choval spíše nedůvěřivě. Podruhé se Hechel v Praze zastavil v červenci 1846 na cestě do Karlových Varů, kam se jel léčit společně se svým známým Michałem Lebowským. Tentokrát vedle muzea, Valdštejnského paláce a katedrály sv. Víta navštívil opět Karolinum, konkrétně promoci doktorů lékařství. Jeho popis je poměrně podrobný, víceméně kritický a o to cennější, že podobná osobní svědectví z uvedené doby nejsou četná. Při rekonstrukci podoby tehdejších promocí se musí historik opírat především o prameny úřední povahy (vyhlášky, matriky, předpisy), jak je to ostatně ve vysvětlivkách ukázáno i na tomto př́padě. Osobně laděný pramen je proto vítaným doplněním dosavadní pramenné báze $\mathrm{k}$ dějinám pražského vysokého učení $\mathrm{v}$ době předbřeznové - tím spíše, že jeho autor dobře znal praxi v akademickém prostředí na jiných

Kierownik Katedry Medycyny Sadowej i Historii Medycyny, in: Jan Grochowski (ed.), Uniwersytet Jagielloński. Złota księga Wydziału Lekarskiego, Kraków 2000, s. 55-61. 
univerzitách. $\mathrm{V}$ mnoha ohledech je doplňkem $\mathrm{k}$ jinému popisu pražské promoce $\mathrm{z}$ pera polského lékaře ve stejném období, konkrétně vilenského porodníka Juliana Albina Moszyńského (1809-1857). Hechelův popis je o něco osobnější a kritičtější, protože nebyl určen $\mathrm{k}$ bezprostřednímu otišstění. Moszyńského text je oproti tomu součástí tištěného cestopisu. ${ }^{3}$ V reáliích a celkovém dojmu z promoce (ale také např́ílad z návštěvy u Václava Hanky) se oba autoři v mnoha ohledech shodují.

\section{Edice překladu pamětí}

\section{Cesta z roku $1843^{4}$}

5. ř́jna

O jedenácté hodině ráno jsme přijeli do Prahy, hlavního města Českého království. Výhled na město, řeku jej dělící a na okolí je moc pěkný. Zastavili jsme se v hostinci Stadt Wien. Právě v těchto dnech tu byly koňské dostihy, proto byly všechny hostince obsazené zvědavými občany, i v této jsme nalezli místo jen stěží. Jakmile jsme si trochu odpočinuli po cestě a převlékli se, vyšli jsme do města, a protože pan Stanisław potřeboval spoustu věcí do své garderoby, opotřebené během té dlouhé cesty, museli jsme se nejprve zabývat nákupem potřebného sukna. Vydal jsem se také za zdejším známým panem Herzem, který byl před pěti lety v Krakově sekretářem na rakouském konzulátu a s nímž jsem se velmi dobře znal. Řekl nám, že v této hospodě je také pan Leon Wodziński z Království, ${ }^{5} \mathrm{~s}$ nímž jsem se seznámil před několika lety v Krakově.

\section{6. ř́ijna}

Dnes jsme byli před obědem s pány Herzem a Wodzińským na koňských dostizích, jež se odehrávaly za městem, kde čeští magnáti přihlašovali své koně k závodům o ceny...

\section{7. ř́ijna}

Dnes před obědem jsme navštívili zdejší starou univerzitu, jež je ukrytá mezi obklopujícími ji domy natolik, že tuto starobylou budovu zvenčí takřka není možné spatřit a odlišit od jiných domů. Zde jsme si prohlédli anatomický kabinet, v němž jsme viděli množství zajímavých př́pravků. Po obědě jsme navštívili velkou všeobecnou nemocnici, v níž se nacházejí lékařské a chirurgické kliniky. Je to solidní nemocnice, ostatně nic nového jsem na ní nezpozoroval...

3 Juljan Albin Moszyński, Podróż do Prus, Saksonii i Czech odbyta w roku 1838-1839, I-II, Wilno 1844. Pasáže týkající se Prahy jsou otištěny ve výboru Josef PolišEnský - Marie Štemberková (edd.), Alma mater Carolina Pragensis. Výbor svědectví cizích návštěvníkủ, Praha 1986, s. 113-116; v českém překladu je vydal také Vincy Schwarz (ed.), Město vidím veliké. Cizinci o Praze, Praha 1940, s. 283-286.

4 W. Szumowski (ed.), Człowiek nauki, II, s. 196-197.

5 Tj. z ruského záboru Polska. 


\section{Cesta z roku $1846^{6}$}

Praha, 17. července

Když jsme vyšli do města, pozorovali jsme jeho vnitřní podobu a pohyb obyvatel. Když jsme šli po starém mostě, spojujícím staré město s novým, objevil se jakýsi člověk, který nám začal popisovat historii svatého Jana Nepomuckého, jak byl z tohoto mostu shozen na rozkaz českého císaře [!] Václava a jak jeho tělo ještě dlouhou dobu plulo ve vodě. Protože nás jeho vyprávění začalo bavit, vzali jsme jej jako svého průvodce a já jsem ho vyzval, aby nás doprovodil do Národního muzea, jež vlasti daroval k veřejnému užitku slavný a učený český př́rodovědec hrabě Šternberk. ${ }^{7}$

Ředitelem tohoto muzea a jeho knihovny je učený Slovan Hanka, ${ }^{8}$ zastihli jsme jej právě v knihovně; řrekl nám, abychom se zapsali do návštěvní knihy, a když se tímto způsobem dozvěděl, že jsem profesorem z Krakova, přivítal mě jako svého krajana a začal naříkat nad smutnou situací Krakova a jiných roztrhaných a rozdělených slovanských zemí. Knihovna sestává z 12000 knih a několika set rukopisů, z nichž některé jsou velmi pěkné a zajímavé; a tak nám mimo jiné ukázal Liber viaticus Episcopalis, rukopis ze 14. století, na pergamenu, s mnoha roztodivnými barevnými kresbami. ${ }^{9}$ Tato kniha nesmírné hodnoty, napsaná před čtyřmi stoletími, je velmi dobře zachována. Týž Hanka mi dal na památku připojené dvě facsimile Jana Husa a Jana Žižky. ${ }^{10}$ Později nám ukázal geognostický kabinet a velice zajímavou předpotopní floru, sesbíranou a popsanou Šternberkem.

Když jsme odsud vyšli, navštívili jsme palác Valdštejna, proslaveného ve třicetileté válce; dosud je v rukou jeho potomka v úplně stejném stavu, jak jej onen frýdlantský kníže postavil. Tady jsme viděli slavnou jeskyni, v níž Valdštejn brával dešt'ové koupele, stejně jako jeho portrét a vycpaného koně, jenž pod ním byl zabit v bitvě u Lützenu; na prvním patře jsme si prohlédli jeho oratorium, v němž poslouchal mše v palácové kapli. Je nesmírně zajímavou věcí vidět ty samé koberce a křesla, na nichž Valdštejn během bohoslužeb klečel a seděl.

Vrátili jsme se do našeho hotelu unaveni chozením a prohlídkami. Chtěl jsem navštívit ještě něco, ale můj společník nebyl zvyklý na podobné prohlídky a zaujatý pouze pěknými tvářičkami Češek mě táhl násilím domů. Po obědě jsme šli znovu do města, chtěli jsme si někde přečíst nějaké francouzské noviny, zdejší vláda však nedovoluje kavárnám brát liberální noviny, takže jsme jich několik navštívili nadarmo. Potom jsme se vydali na ostrov na řece Vltavě, zvaný Sophien-Insel, kde měl dnes být velký koncert, ale vydatný déšt', který začal padat kolem šesté, nedovolil hostům se sejít a my sami, navštívivše tam velmi pěkné malé lázně, jsme se museli utéci do divadla fiakrem; dávali kus s názvem Stadt und

6 W. Szumowski (ed.), Człowiek nauki, II, s. 427-432.

7 Kašpar Maria hrabě Šternberk (1761-1838), český šlechtic, př́rodovědec, ale také kanovník řezenské kapituly; jedna ze zakladatelských osobností Národního muzea, korespondující mj. s Johannem Wolfgangem Goethem.

8 Václav Hanka (1791-1861), přední český buditel, slavista a padělatel.

9 S velkou pravděpodobností tzv. „Liber viaticus“ biskupa Jana ze Středy, iluminovaný breviář z padesátých let 14. století, uložený v Knihovně Národního muzea pod signaturou XIII A 12. Nejnověji k němu Pavel BroDSKÝ - Kateřina SPURNÁ - Marta VACulínOvÁ, Liber viaticus Jana ze Středy, I-II, Praha 2016.

10 Podle údajů editorů jsou vlepeny do rukopisu. Srov. Zbigniew JABŁoŃSKI - Alojzy PreissnER, Katalog rękopisów Polskiej Akademii Nauk w Krakowie. Sygnatury 1811-2148, Wrocław - Warszawa - Kraków 1962, s. 40-41. 
Land; hostoval herec Wallner ${ }^{11}$ a svou roli odehrál velmi dobře, jiní herci byli průměrní a obecenstva celkem málo.

Po divadle jsme se vrátili na večeři a na noc do naší hospody. Následujícího dne jsme měli odjet do Karlových Varů, ale protože byla na zítřek ohlášena pěkná opera Montecchi e Capuletti, ${ }^{12} \mathrm{v}$ níž měla vystupovat v roli Julie vychvalovaná zpěvačka Soukop, rozhodli jsme se zdržet ještě jeden den.

\section{8. července}

Dnes ráno jsme pili kávu $\mathrm{v}$ jedné $\mathrm{z}$ lepších kaváren ve městě, protože nám včera $\mathrm{v}$ našem hotelu dali mizernou kávu. Po snídani jsem svého kolegu doprovodil na univerzitu, kde se před polednem měla konat veřejná promoce tř́ kandidátů na doktora medicíny. ${ }^{13} \mathrm{Když}$ jsme přrišli do univerzitní auly, zastihli jsme ceremoniál již započatý a tak velké množství zvědavých mužù a žen, že nebylo nikde místo k sezení; já vida, že na vyvýšeném chóru, kde seděli profesoři, je ještě mnoho prázdných míst, vydal jsem se tam se svým společníkem a obsadil jsem místo vedle jednoho profesora, jemuž jsem řekl latinsky, že jsem také profesorem medicíny a že nenaleznuv nikde místo, dovolil jsem si k němu přisednout, načež mi podal vlídně ruku a vybídl mě k usednutí.

Aula, v níž se promoce konala, je ohromný a vysoký sál, kam se vejde přes 500 lidí, v jejím středu jsou lavice pro veřejnost jako v kostele, $v$ čele je cosi jako velká dvojitá katedra, před níž stáli tři kandidáti a na katedře nad nimi seděl profesor-promotor a tehdejší děkan lékařské fakulty; ${ }^{14} \mathrm{z}$ obou stran byla vyvýšená křesla, jedno po pravé straně pro rektora univerzity Jeronýma Zeidlera, ${ }^{15}$ profesora teologie, seniora ${ }^{16}$ a opata kanovníků praemonstratensium, po levé katedra s baldachýnem, nyní prázdná, pro pražského arcibiskupa a kanclére univerzity. ${ }^{17} \mathrm{U}$ těchto kateder byl po obou stranách vyvýšený chór se sedadly pro profesory této školy a na tomto chóru jsem se usadil také já se svým společníkem.

Ve chvíli, kdy jsme přišli, četl rektor latinsky projev a v něm prohlásil, že tři kandidáti po složení př́sných zkoušek a disputaci (která se odehrála již před naším příchodem) si zasloužili titul doktora. Poté tajemník fakulty přečetl kandidátům př́isahu, při níž odložili své kordy. Každý z nich byl oblečen v černém fraku, krátkých kalhotách, bílých punčochách a střevících. Následně děkan přečetl jakýsi projev, jemuž jsem kvưli vzdálenosti a tichému čtení nemohl rozumět, pozval kandidáty ke své katedře, každému pověsil [na krk] řetěz a předal pečetní prsten a knihu za proslovi̊ a napomenutí při takových obřadech běžných.

11 Patrně Franz Wallner (1810-1876), rakouský herec. V letech 1836-1848 bylo jeho domovskou scénou divadlo ve vídeňském Josephstadtu, ale velmi často hostoval.

12 Opera italského skladatele Vincenza Belliniho (1801-1835) z roku 1830.

13 V př́íslušné matrice je k datu 18. 7. 1846 následující záznam: „D[ominus] Unterweger Guielmus Pragenus, D[ominus] Roth Antonius Boh. Sirbiz atque D[ominus] Cžiharz Antonius Moravus Iglaviens[is] in aula promotore celeb. D. Prof. Popel publice laurea doctoratus medici condecorati.“ Jednalo se tedy o slavnostnější formu promoce, než byly běžné. Archiv Univerzity Karlovy, fond Matriky, sign. M 64, Matricula facultatis medicae Pragensis ab anno 1784 (1784-1873), p. 105. Program je dochován v rukopise Hechelových pamětí, jména promovaných se shodují. Srov. Z. JabŁońsKi - A. Preissner, Katalog, s. 41.

14 Josef Reisich (1795-1865), anatom, vyučoval také fyziologii a patologii, znám jako výborný praktik.

15 Josef Jeroným Zeidler (1790-1870), český duchovní a politik, od roku 1824 řádný profesor dogmatiky a polemické teologie na teologické fakultě Karlo-Ferdinandovy univerzity.

16 V originále ,emeryta“.

17 Arcibiskupem a po formální stránce tím pádem také kancléřem univerzity byl v této době Alois Josef baron Schrenk z Notzingu (1802-1849). 
Teprve pak jeden z kandidátů přečetl latinsky obvyklé poděkování kancléri, rektorovi, profesorům a promotorovi a německy prítomné veřejnosti. Po každém z těchto ceremoniálních aktů bylo z velkého chóru slyšet hudbu podobnou takové, jaká je běžná v melodramatech.

Dále jeden z kandidátů přečetl německy rozpravu, v níž dokazoval, že nástroj sluchu je nejšlechetnějším ze všech smyslů; tato rozprava byla dosti dlouhá, pěkně a květnatě napsaná. Na tuto rozpravu odpověděl (písemně) profesor Popel ${ }^{18}$ a dokazoval, že prvenstvo mezi ostatními smysly náleží zraku; jeho rozprava, do níž zahrnul celou anatomii oka, byla na takovou ceremonii př́liš dlouhá a pro svět medicíny a vědy navíc př́liš povrchní, zkrátka naprosto nepotřebná a jen zbytečně zabírající čas. Po této rozpravě rektor znovu četl něco latinsky, vyhlásil kandidáty doktory a chválil jejich vědomosti; naprosto jalové žvásty. Hned u auly se nachází malá kaple, $\mathrm{k}$ níž se po skončené ceremonii vydal rektor a kandidáti na čtenou mši, ale profesoři ji obešli a utekli domů.

Rektor byl oblečen $\mathrm{v}$ bílém rouchu s rektorským řetězem na krku, profesoři pak v zelených uniformách se zlatem vyšívanými límci a rukávy. Obřad trval téměř tři hodiny, což je - pokud se to často opakuje, jak tomu na tak velké univerzitě bývá - pro profesory zbytečně trýznivé a obtěžující, zvláště zbytečnou věcí pak je soustavné čtení nějakých proslovů a rozprav učiteli, když jim jejich psaní zabírá mnoho času a přitom nejsou takové povahy, aby mohly být otištěny. Každý koneckonců ví, že taková veřejná promoce je jen pouhou ceremonií a mohla by proto být stejně slavnostní, ale méně nudná. Na konci obřadu pedelové rozdávali latinský program, a protože jsem seděl vedle profesorů, dali jeden také mně.

Po skončení akademického zasedání jsme navštívili galerii obrazů hraběte Nostice; prohlédl jsem si ji rychle, protože kromě několika dobrých obrazů německé a holandské školy jsem tu nic velkého nenalezl. Oběd jsme jedli na ostrově Sophien-Insel, nebylo to nic zvláštního. Po cestě na oběd jsme na ulici natrefili na našeho biskupa Łętowského, ${ }^{19}$ který se jede také léčit do Karlových Varů, kde se, dá-li Bůh, budeme vídat častěji; přinejmenším hned na začátek tam budu mít jednoho známého.

Po obědě jsme byli ve slavné nové kavárně Café Oriental u zdejší železnice. Ve všech ohledech si ten název zasluhuje, protože je tu vše přepychově zařízeno ve východním stylu; přehozy, lze-li to tak rríci, zlaté a stř́ibrné, stěny zdobí ty nejkrásnější arabesky a dvě neustále tryskající fontány udržují př́ijemný chládek. Všechny nápoje jsou toho nejlepšího druhu, ale také nesrovnatelně dražší než kdekoli jinde v Praze, a tak šálek kávy stojí 12 stříbrných krejcarů. Je tu také množství novin, dokonce i francouzský Journal des Débats, pokud v něm není nic proti Rakousku, jinak ho policie konfiskuje, tak jako Journal ze dne 3. července, $v$ němž je slavný Montalembertů $\mathrm{v}^{20}$ proslov proti Rakousku, který žádná čitárna, a tím spíše veřejná kavárna, nezískala.

Zůstali jsme tu přes hodinu a vydali se pomalu do divadla na ohlášenou operu Montecchi e Capuletti. Divadlo bylo plné diváků a opera byla velmi dobře provedena, zvláště vynikla mladá, začínající zpěvačka slečna Soukop (což je určitě upravené ze Saukopf), o nic méně

18 Matěj Popel (1798-1865), český lékař, od roku 1832 profesor soudního lékařství a zdravotní policie na pražské univerzitě.

19 Ludwik Łętowski (1786-1868), krakovský pomocný biskup, doktor honoris causa Jagellonské univerzity a známá osobnost soudobého kulturního a veřejného života v Krakově. Srov. H. BARYcz, Wśród gawędziarzy, s. $117-156$.

20 Nejspíše Charles Forbes René de Montalembert (1810-1870), francouzský publicista a historik katolické orientace, sympatizující s polským osvobozeneckým hnutím. 
si potlesk zasloužila také slečna Ney v roli Romea. Po divadle se můj společník vydal ještě na večeři a já na lože.

\title{
19. července, neděle
}

Vstávali jsme dost časně, a když jsme se oblékli, šli jsme do Východní kavárny ${ }^{21}$ na snídani, odkud jsme si, poněvadž bylo velké horko a daleko do katedrály, vzali drožku a odjeli tam. Je to starobylý kostel, a ačkoli má menší význam než kolínský, uvnitř se mu v mnohém podobá; zastihli jsme tu množství lidí. Uprostřed kostela je velký mramorový náhrobek českých králů. Celkem pěkný je obraz byzantské školy, představující na zlatém pozadí Kristovu hlavu; visí na jednom bočním sloupu. Viděl jsem onen velký náhrobek svatého Jana Nepomuckého ze strríbra, před nímž jsem nalezl množství modlících se lidí a na němž není kromě obrovského množství stř́bra nic uměleckého k vidění; v kapli svatého Zikmunda je velký svícen, ${ }^{22}$ jenž má pocházet ze Šalomounovy svatyně, byl přivezen knížetem Vladislavem a darován tomuto kostelu atd.

Odtud jsme se vrátili pěšky na oběd domů, po obědě jsme sbalili své věci a po třetí jsme se vydali na poštu; zde jsme čekali do čtvrté, a díky včasnému příchodu jsme dostali dvě místa v kabrioletu, v úplně novém povozu; kromě našeho jely tou samou cestou ještě dva jiné povozy. Projížděli jsme různé vsi a malá městečka a druhého dne mezi osmou a devátou jsme zastavili v Karlových Varech.

MAREK ĎURČANSKÝ

\section{Das Karolinum mit den Augen eines Krakauer Professors: die Pragbesuche des Arztes Fryderyk Hechel im Oktober 1843 und im Juli 1846}

\author{
ZUSAMMENFASSUNG
}

Der Beitrag besteht aus einer biografischen Einleitung und der Übersetzung einer Quelle zur Geschichte der Karl-Ferdinands-Universität im 19. Jahrhundert: zweier Auszüge aus den Erinnerungen des polnischen Arztes Fryderyk Hechel (1795-1851). Dieser Professor der Jagiellonenuniversität in Krakau besuchte Prag zweimal (1843 und 1846) und beschrieb seine beiden Besuche in seinen Erinnerungen. Der zweite Auszug enthält eine einzigartige, detaillierte Beschreibung einer Promotion von Doktoren der Medizin in der großen Aula des Karolinums.

Deutsche Übersetzung Wolf B. Oerter

Marek Ďurčanský

Ústav dějin a archiv UK, Praha

marek.durcansky@ruk.cuni.cz

21 Patrně dříve uvedený podnik Café Oriental.

22 Tzv. Jeruzalémský svícen, který se dostal do svatovítského pokladu po dobytí Milána v roce 1158 jako součást kořisti přivezené Vladislavem II. Byl považován za původní svícen z Šalomounova chrámu, ve skutečnosti se jedná o raně románské dílo z oblasti Maasy a Mosely. 